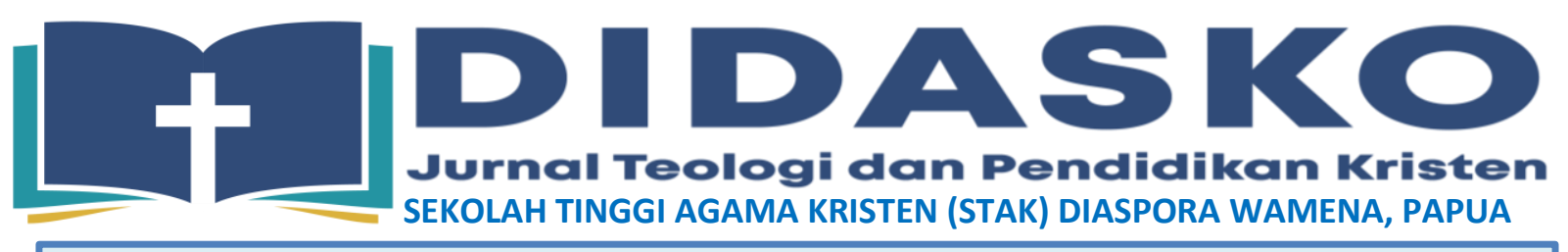

Volume 1 Nomor 1 (April 2021)

Web STAK DIASPORA Wamena: http://stakdiaspora.ac.id

Web DIDASKO: http://e-journal.stakdiaspora.ac.id/index.php/didasko/index

\title{
TELAAH PERAN ORANG TUA DALAM MEMBANGUN EKOSISTEM \\ SUKACITA KELUARGA PADA MASA KENORMALAN BARU \\ DARI SUDUT PANDANG TEOLOGI PENTAKOSTA
}

\author{
Kosma Manurung \\ Program Studi Magister Teologi STT Intheos Surakarta \\ kosmamanurung@sttintheos.ac.id
}

\begin{abstract}
The purpose of this article's research is to examine the role of Christian parents in building the sacred ecosystem in the family during the new normal from the perspective of Pentecostal theology. The method used is descriptive and literature review. This article discusses how the Bible views joy, the importance of joy to believers in particular in the new normal, and the role of parents in building a joyful ecosystem in the Christian family. Through the research results of this article, there are six practical ways that parents can apply in building an ecosystem of joy in the family of believers, namely through behavior that does not like anger, avoiding fighting with partners, building a culture of joking, living by the moral standards that the Bible teaches, develop love language communication, and be role models.
\end{abstract}

Keywords: joy; family; Christian family; joy ecosystem; parenting; Pentecostalism; Pentecostal theology

\begin{abstract}
Abstrak
Maksud dari penelitian artikel ini ingin menelaah peran orang tua Kristen dalam membangun ekosistem sucakita di keluarga pada masa kenormalan baru dari sudut pandang teologi Pentakosta. Metode yang digunakan adalah deskriptif dan kajian literatur. Artikel ini membahas bagaimana pandangan Alkitab tentang sukacita, arti penting sukacita bagi orang percaya secara khusus di masa kenormalan baru, dan peran orang tua dalam membangun ekosistem sukacita di keluarga Kristen. Lewat hasil penelitian artikel ini ada enam cara praktis yang orang tua bisa terapkan dalam membangun ekosistem sukacita di keluarga orang percaya yaitu melalui perilaku yang tidak suka marah-marah, menghindari bertengkar dengan pasangan, membangun budaya senda gurau, hidup dalam standar moral yang Alkitab ajarkan, mengembangkan komunikasi bahasa cinta, dan jadi teladan.
\end{abstract}

Kata Kunci: sukacita; keluarga; keluarga kristen; ekosistem sukacita; pola asuh; pentakostalisme; teologi pentakosta 


\section{PENDAHULUAN}

Manusia adalah makhluk hidup dengan berbagai periode waktu yang masing-masing periode waktu itu memiliki proses dan keunikannya sendiri (Rossandy, 2016). Hal ini berarti bahwa manusia baik suka atau tidak suka dan sadar atau tidak sadar mereka adalah makhluk yang terikat oleh waktu dan hidup dalam batasan waktu (Jannah, Yakob, \& Julianto, 2017). Manusia normal umumnya mengalami proses kelahiran, masa kanak-kanak, bertumbuh remaja, dewasa, menikah, membesarkan anak, menjadi tua, dan akhirnya kembali pada Tuhan sebagai pemilik kehidupan. Dalam setiap periode kehidupan ini ada banyak hal maupun proses kehidupan yang dialami yang akhirnya membentuk kebiasaan perilaku yang kemudian menjadi karakter dari dirinya (Xiao, 2018).

Alkitab menggambarkan keluarga adalah tempat terbaik dalam mendidik anak terutama dalam membentuk perilaku dan karakter anak (Roy \& Yosef, 2019). Pada kenyataanya banyak keluarga tidak menjalankan fungsinya dengan benar sehingga menyebabkan banyak anak yang bertumbuh besar merasa terbuang, tidak disayang, dan tertolak.(Hadi, 2019) Kalau tidak segera ditangani dengan benar anak-anak ini ketika remaja memiliki kecenderungannya salah dalam pergaulan yang dalam banyak kasus semakin terjerumus dalam pergaulan bebas, drug, kejahatan, dan penyakit sosial lainnya bahkan tak jarang akan keluar masuk penjara (Tari \& Tafonao, 2019). Selanjutnya ketika mereka menikah dan punya anak kebiasaan buruk ini akan diteruskan ke generasi selanjutnya yang mewarisi perilaku tidak baik dari orang tua mereka, apabila tidak ada campur tangan Tuhan hal ini akan berlangsung terus seperti bola salju yang menggelinding dengan dampak kerusakan yang makin besar (Manurung, 2020c).

Alkitab menawarkan solusi ilahi bagaimana seharusnya pola pendidikan keluarga dalam mendidik dan membentuk perilaku maupun karakter anak yang bukan sekedar akan jadi bekal hebat bagi masa depan anak itu tapi bagaimana anak itu memainkan peran aktif untuk menjadi berkat lewat keberadaannya (Budiyana, 2018). Menurut Alkitab dalam pendidikan keluarga kuncinya ada para orang tua dalam hal ini ayah dan ibu yang merupakan elemen utama dalam mendidik dan membesarkan anak-anak mereka. Artinya di tangan kedua orang tualah ekosistem harmoni keluarga itu terletak (Juanda \& Eveline, 2018). Alkitab juga menyatakan bahwa sukacita Tuhan adalah kekuatan dan perlindungan bagi orang percaya dan keluarganya (Neh. 8:10). Terkait dengan ekosistem sukacita dalam keluarga tentunya prinsip yang sama juga berlaku di mana di tangan kedua orang tualah ditentukan baik atau buruknya ekosistem sukacita di sebuah keluarga itu (Manalu, 2020). Dalam tingkatan kebutuhan manusia yang dikumandangkan oleh Abraham Maslow aktualisasi diri adalah kebutuhan puncak manusia yang seharusnya dipenuhi (Iskandar, 2016). Peneliti dalam artikel ini bermaksud menguraikan pandangan Alkitab dari sudut pandang teologi Pentakosta bagaimana peran orang tua membangun ekosistem sukacita dalam keluarga Kristen sehingga para anggota keluarga bisa mengaktualisasikan sukacita dalam keseharian hidup mereka pada masa kenormalan baru.

\section{METODE PENELITIAN}

Peneliti memilih metode kualitatif dengan pendekatan deskriptif dan kajian literatur dalam penelitian ini dikarenakan secara karakteristiknya penelitian kualitatif dapat menggambarkan serta mewakili pemaknaan dari sesuatu yang sedang diamati ataupun diteliti (Zaluchu, 2020). Deskriptif sendiri merupakan bagian dari metode kualitatif yang dalam penelitian artikel ini digunakan untuk menggambarkan pandangan Alkitab secara khusus dari sudut pandang teologi Pentakosta tentang 
sukacita. Selain itu deskriptif juga digunakan untuk menjelaskan arti penting sukacita bagi orang percaya masa kini serta peran orang tua Kristen dalam membangun ekosistem sukacita di keluarga. Untuk memperkaya ide, gagasan, dan pemahaman yang peneliti bangun dalam artikel ini, peneliti menggunakan kajian literatur yang relevan dengan topik pembahasan yang bersumber dari buku dan artikel jurnal yang terbit lima tahun terakhir akar memiliki dasar kebaharuan.

\section{HASIL DAN PEMBAHASAN}

\section{Pandangan Alkitab Tentang Sukacita}

Alkitab bagi orang percaya merupakan buku yang berisi panduan hidup yang mengatur kehidupan manusia secara khusus kehidupan orang percaya, bagaimana berhubungan dengan Allah juga terkait dengan bagaimana orang percaya berkomunikasi dan berinteraksi dengan orang percaya lainnya maupun dengan sesama manusia yang belum mengenal dan mengalami anugerah keselamatan Tuhan (Manurung, 2019). Alkitab baik itu Perjanjian Lama maupun Perjanjian Baru banyak memuat serta menjelaskan bagaimana berkat yang berupa sukacita itu memenuhi, berproses serta memberikan dampak kebaikan bagi orang percaya di masa lalu yang tentunya juga bagi orang percaya di masa kini (Sukono, 2019). Raja Daud dalam Mazmur 37:4 menyarankan kepada setiap orang percaya untuk bergembira karena Tuhan. Kata bergembira jika mengacu pada bahasa aslinya bisa dimaknai menjadikan kebiasaan untuk berbahagia serta menikmati kesenangan yang luar biasa, yang dalam arti lain adalah bersukacita secara dalam dan luar biasa. Nehemia menyatakan dengan tegas bahwa sukacita dari Allah itu adalah perlindungan kita yang dalam terjemalan lain dimengerti sebagai kekuatan orang percaya (Neh. 8:10).

Perjanjian Baru dibuka dengan sebuah peristiwa besar yaitu kelahiran Tuhan Yesus dengan sukacita surgawi, para gembala yang didatangi oleh malaikat menyaksikan dengan mata kepala mereka sendiri bagaimana bala tentara surga memuji Allah penuh dengan sukacita menyaksikan kelahiran Kristus (Cristian Runturambi, 2018). Rasul Paulus menandai sukacita sebagai buah roh yang artinya sukacita ini merupakan bagian dari karya Roh Kudus dalam kehidupan orang percaya (Sitompul, 2017). Kesepakatan pemahaman di kalangan teolog Pentakosta menyatakan bahwa teologi Pentakosta adalah teologi yang dibangun dari pemahaman bahwa apapun yang dikatakan Alkitab pasti benar dan pasti terjadi (Sitompul, 2017). Lebih jauh kaum Pentakosta meyakini benar bahwa Allah melalui Roh Kudus menginspirasi para penulis Alkitab untuk menulis apa yang ingin Allah sampaikan kepada umat-Nya. Terkait dengan sukacita ini, kalangan Pentakosta meyakini benar bahwa karakteristik umat Allah sejati haruslah yang mencerminkan sukacita teristimewa sukacita dalam memuji, membaca Alkitab, melakukan kehendak Tuhan, dan mengasihi sesama (H. E. R. Siahaan, 2017). Intinya dalam menjalani kehidupan setiap harinya orang percaya harus dipenuhi sukacita surga dan memancarkan sukacita surga di manapun dan dalam kondisi apapun (Zaluchu, 2019).

\section{Arti Penting Sukacita Bagi Orang Percaya Masa Gini}

Sukacita penting bagi orang percaya masa kini karena sukacita adalah salah satu sarana yang Tuhan pakai untuk menjawab kebutuhan orang percaya (Pranoto, 2017). Raja Daud mengambarkan dengan sangat gamblang bahwa ketika umat Tuhan bersukacita karena Tuhan maka Tuhan akan memberikan kepada mereka kerinduan terdalam dari hati mereka (Maz. 37:4). Melalui pemahaman ini raja Daud ingin membagikan bahwa Tuhan bisa menjadikan sukacita sebagai faktor atau alasan untuk menjawab kebutuhan umat-Nya. Dengan kata lain, sukacita adalah salah satu kunci untuk mendatangkan jawaban Allah atas hidup orang percaya (Tua, 2017). Ada kisah lainnya yang dicatat oleh Alkitab di mana ketika Tuhan memberikan strategi kepada Yosua untuk merebut 
dan menaklukan Yerikho yang kotanya dikelilingi benteng tembok yang begitu kuat dan tidak bisa ditembus. Tuhan memerintahkan Yosua untuk mengelilingi tembok kota itu selama tujuh hari dan hari dan ketika hari ketujuh harus mengelilingi tujuh kali maka Yosua menyuruh bangsa itu bersorak dan runtuhlah tembok itu. Mengacu pada bahasa aslinya kata bersorak di sini berasal dari kata Ibrani ruwa' yang bisa dimaknai dengan teriakan sukacita. Artinya teriakan sukacita karena kemenangan yang Tuhan berikan. Bagi kaum Pentakosta yang menyandarkan pemahaman iman mereka pada keyakinan bahwa apa saja yang Allah lakukan di masa lalu pasti benar dan Allah yang sama bisa melakukan hal itu hari ini bagi orang percaya (Soesilo, 2018). Terkait dengan sukacita kalangan Pentakosta meyakini dengan benar bahwa sukacita adalah salah satu sarana yang Tuhan pakai untuk menjawab kebutuhan orang pilihanNya (Zaluchu, 2019).

Sukacita dari Tuhan adalah kekuatan orang percaya (Prabowo, 2020). Nehemia dengan tegas menyampaikan pada generasinya yang juga tentunya hal yang sama berlaku secara otomatis bagi orang percaya saat ini bahwa sukacita dari Tuhan adalah kekuatan orang percaya (Neh. 8:10). Tak bisa dipungkiri memang pengetahuan dan pemahaman seseorang berbanding lurus dengan perilakunya maksudnya di sini ketika seseorang memahami sesuatu maka perilakunya terkait sesuatu itu akan berubah (Keriapy, 2020). Misalkan saja pengetahuan dan pemahaman terkait virus Covid 19 begitu mengubah cara orang berperilaku dalam keseharian. Gambaran Alkitab melalui Nehemia ini jelas bahwa sukacita yang merupakan kekuatan orang percaya ini berarti kuat atau tidaknya umat pilihan di masa lalu dan orang percaya di masa kini dalam menjalani kehidupan yang Tuhan inginkan terhubung erat bagaimana mereka mengerti, memahami, dan menghidupi sukacita Tuhan dalam keseharian hidup mereka. Kegemaran kaum Pentakosta pada Alkitab membangun keyakinan mereka bahwa pernyataan Nehemia ini adalah pernyataan yang harus dihidupi oleh orang percaya masa kini (Arrington, 2020).

Sukacita yang Tuhan berikan kepada orang percaya selain berfungsi sebagai salah satu sarana yang Tuhan jadikan alasan untuk memberkati orang percaya dan memberikan stamina yang orang percaya butuhkan untuk menjalani kehidupan iman dan keseharian mereka, sukacita dari Tuhan juga merupakan perlindungan bagi orang percaya. Sukacita melindungi orang percaya dari serangan yang merusak pikiran, membuat kuatir dan stress yang bisa berujung pada struk dan kematian (Friedman, 2016). Orang yang menjalani kehidupannya dengan penuh sukacita maka hal ini akan menjauhkan segala bentuk stres yang bisa merusak hidupnya. Selain itu dalam sudut pandang medis orang yang bersukacita secara otomatis akan meningkatkan imun tubuhnya yang dalam konteks keadaan saat ini di mana pendemik covid 19 begitu masif merusak kesehatan umat manusia, sukacita Tuhan justru melindungi manusia dengan cara meningkatkan imun tubuh manusia. Seperti Nehemia yang meyakini sukacita Tuhan itu adalah perlindungan, kalangan Pentakosta juga memiliki keyakinan yang sama bahwa sukacita dari Tuhan adalah perlindungan yang melindungi orang percaya secara khusus pada masa kini dari berbagai bentuk pikiran yang salah, stres, ketakutan, dan meningkatkan imun tubuh untuk menguatkan orang percaya (H. E. Siahaan, 2015).

Rasul Paulus menulis bahwa sukacita merupakan buah roh (Gal. 5:22). Artinya jika ada orang yang mengaku bahwa dia dipenuhi Roh Kudus namun hidup kesehariaannya tidak memperlihatkan sukacita maka ada yang salah tentang klaim orang tersebut. Orang yang bersukacita hidupnya pasti bersemangat dan menarik perhatian orang lain di sekitarnya. Bayangkan saja jika ada orang yang mengaku percaya Tuhan namun hidupnya marah-marah terus, apa hal yang menarik dari orang yang suka marah-marah, bagaimana orang melihat rupa Kristus dari orang yang marah-marah, bagaimana orang tersebut akan menjadi berkat bagi orang lain (Manurung, 2020b). Ketika ada orang yang mengaku orang percaya dan hidupnya penuh sukacita dan ramah maka hal itu pasti akan menarik orang lain untuk datang. Kaum Pentakosta mengerti benar sebagai buah roh sukacita dalam kehidupan orang percaya bisa menarik perhatian orang lain di sekitarnya dan 
menjadi jembatan dalam membangun koneksi juga tentunya dalam kaitan dengan pemberitaan kabar baik yang merupakan panggilan setiap orang percaya (Stevanus, 2018a).

\section{Peran Orang Tua Kristen Membangun Ekosistem Sukacita}

Alkitab mengajarkan bahwa keluarga adalah tempat pendidikan yang paling utama dalam mengajarkan, mengarahkan, dan mendidik anak-anak mereka dalam jalan yang Allah inginkan anak itu lalui sehingga ketika bertumbuh dewasa anak tersebut akan jadi berkat bagi semua orang (Stevanus, 2018b). Di sebuah keluarga peran kedua orang tua dalam hal ini ayah dan ibu adalah yang terutama dalam mendidik dan membesarkan anak-anaknya. Terkait dengan membangun ekosistem sukacita maka ayah dan ibulah elemen utama yang memainkan peran penting dalam membangun ekosistem sukacita ini. Peneliti menemukan paling tidak ada enam hal yang bisa ayah dan ibu lakukan untuk membangun ekosistem sukacita di rumah tangga. Adapun keenam hal itu sebagai berikut di bawah ini:

\section{Jangan Marah-Marah}

Hal pertama yang kedua orang tua harus lakukan dalam membangun ekosistem sukacita adalah dengan tidak marah-marah (Hendra, 2018). Peneliti tidak melarang orang tua untuk memarahi anak mereka karena Alkitab juga mengajarkan ada saatnya dalam keadaan tertentu orang tua wajih hukumnya untuk marah. Yang peneliti maksudkan dengan marah-marah adalah janganlah karena hal-hal kecil atau remeh membuat orang tua marah. Artinya hanya karena hal sepele yang mestinya cukup dibicarakan baik-baik atau diajari sekali lagi saja maka si anak sudah mengerti dan tidak perlu sampai memuntahkan kemarahan yang meledak-ledak (Suteja, 2017). Kalangan Pentakosta mengerti bahwa kemarahan yang tidak pada tempatnya dan dilakukan dalam waktu yang salah sifatnya pasti merusak (Manurung, 2020b). Setiap kali kemarahan meluap-luap maka pastinya akan secara langsung menghancurkan ekosistem sukacita yang sedang dibangun.

\section{Jauhi Pertengkaran Dengan Pasangan}

Pertengkaran dengan pasangan dalam hal ini pertengkaran ayah dan ibu sangat mempengaruhi sukacita rumah tangga (Saragih \& Hasugian, 2020). Orang tua yang kesukaan alias hobinya suka bertengkar dan saling melukai dalam bahasa verbal apalagi berlanjut dengan kontak fisik, hal itu tentunya sangat melukai hati anak-anak mereka serta berbekas dalam diingatan mereka. Maka dari itu untuk membangun ekosistem sukacita di keluarga, kedua orang tua harus sebisa mungkin menjauhkan diri dari pertengkaran pasangan (Juanda \& Eveline, 2018). Kaum Pentakosta menyadari benar dampak negatif dari pertengkaran pasangan yang jika tidak dibawa dalam terang Tuhan untuk menyelesaikannya akan berujung pada perceraian yang bahkan lebih parah lagi dampaknya karena yang akan menjadi korban dan terluka adalah anak-anak (Novalina, 2020). Jadilah seorang pemaaf yang hebat bagi pasangannya dan tambahkan kesabaran serta ingatkan diri akan rasa sayang mendalam yang pernah dimiliki ketika jatuh cinta dulu.

\section{Membangun Budaya Senda Gurau}

Budaya senda gurau harus dibangun oleh kedua orang tua terutama dalam keluarga Kristen, karena dengan terbangunnya kebiasaan bercengkarama dan bersenda gurau selain memutus mata rantai otoriter juga sangat baik bagi keharmonisan keluarga (Surya Gani \& Budi Lestari, 2018). Hubungan anak dan orang tua akan sangat dalam dan tanpa tembok ketika orang tua bisa bersenda gurau dengan anak-anaknya, juga anak-anak merasa nyaman karena diperlakukan sederajat dan dianggap layak untuk dijadikan teman bersenda gurau. Senda gurau antar anggota keluarga membuat kelekatan dan ikatan yang semakin kuat antar anggota. Dari sudut pandang anak-anak, ketika melihat ayah dan ibu suka bersenda gurau anak-anak akan merasa sangat senang karena 
mereka tahu hubungan kedua orang tua mereka pastilah sangat harmonis (Sudaryanti, 2017). Keharmonisan hubungan yang di dalamnya ada senda gurau antar pasangan dan anggota keluarga ini sangat dianjurkan oleh kalangan Pentakosta dikenal sebagai kaum yang menyukai bersuka cita (H. E. R. Siahaan, 2017). Senda gurau antara orang tua juga antar orang tua dan anak menghasilkan terbentuknya ekosistem sukacita di rumah tangga.

\section{Hidup Dalam Standar Moral Yang Alkitab Ajarkan}

Hal yang penting lainnya untuk dipahami dan dihidupi oleh orang tua apabila ingin membangun ekosistem sukacita adalah menghidupi standar moral yang diajarkan oleh Alkitab (Katarina \& Darmawan, 2019). Standar moral ajaran Alkitab yang peneliti maksudkan dalam artikel ini yaitu di mana para orang tua menerapkan pada diri mereka standar moral yang Alkitab ajarkan semisal jangan berzinah, mencuri apalagi korupsi dan berbagai tindak kejahatan lainnya. Karena ketika standar moral itu dilanggar maka akan berdampak pada keluarga secara keseluruhan. Seorang anak yang orang tuanya ditangkap KPK karena kasus korupsi akan merasa sangat malu terlebih lagi jadi bahan bully oleh teman-temannya (Sunariyanti, 2020). Contoh lainnya ketika orang tua ketahuan terlibat dalam perzinahan dan hal ini diketahui oleh pasangannya dan anak-anak maka sudah pasti keharmonisan rumah tangga itu sangat terganggu. Hal inilah mengapa kaum Pentakosta beranggapan pentingnya orang percaya secara khusus orang tua di keluarga Kristen untuk hidup dalam standar moral yang diajarkan oleh Alkitab (Zaluchu, 2019).

\section{Mengembangkan Komunikasi Bahasa Cinta}

Berkomunikasi dalam bahasa cinta adalah hal lainnya yang perlu orang tua ajarkan dan tunjukan dalam keseharian di keluarga. Bahasa cinta merupakan bahasa penerimaan dan sekaligus juga bahasa ekspresi dari manusia yang mana melaluinya mereka berkomunikasi dan ingin ditanggapi oleh orang lain (Chapman \& Campbell, 2018). Artinya melalui bahasa cinta ini orang tersebut akan merasa penerimaan serta penghargaan dan begitu juga sebaliknya ketika bahasa cinta mereka disepelekan atau diremehkan maka yang keluar adalah rasa marah dan sakit hati (Chapman \& Campbell, 2018). Ketika orang tua dalam hal ini ayah dan ibu saling memahami bahasa cinta pasangan mereka, juga memahami bahasa cinta anak-anak mereka dan lebih lagi berkomunikasi dan terhubung dengan bahasa cinta mereka maka ekosistem suka cita akan terbangun yang berujung pada terciptanya keharmonisan keluarga. Salah satu karakteristik kaum Pentakosta yaitu keluwesan dan kesimpelannya (Sutoyo, 2018). Luwes dan simpel yang dimaksudkan di sini tentunya terkait dengan hal yang positif untuk hidup dan melayani Tuhan. Terkait dengan berkomunikasi melalui bahasa cinta kaum Pentakosta selalu menghidupi bahwa ketika terkait dengan Alkitab dan keutuhan serta keharmonisan keluarga maka semuanya harus dilakukan dengan semaksimal mungkin (Manurung, 2020a).

\section{Jadilah Teladan}

Alkitab memberikan gambaran terkait soal pola didik dan asuh anak bagaimana orang tua itu bertindak sebagai guru pertama dan terutama bagi anak-anak mereka (Tandy K, 2016). Alkitab menuntut orang tua bukan sekedar mengajarkan anak-anak mereka tentang sesuatu tetapi juga menjadi contoh hidup yang bisa dilihat dan dijadikan role model oleh anak-anak mereka bagaimana mereka melakukan dan bereaksi terhadap sesuatu (Eliasaputra, Novalina, \& Siahaan, 2020). Ketika orang tua gagal menunjukkan bagaimana bertindak atau merespon maka anak-anak di rumah akan kehilangan pembelajaran terpenting dalam hidup mereka. Menilik sejarah bagaimana pelayanan Pentaksota berkembang pesan di penjuru dunia juga di Indonesia maka tak bisa dilepaskan dari penjangkauan pelayanan anak dan keluarga (Supatra, 2019). Bagi kaum Pentaksota anak adalah generasi penerus gereja sedangkan keluarga adalah bagian terkecil yang bisa menjadi contoh surga 
atau neraka itu seperti apa. Oleh karenanya tidak heran apabila pelayanan Pentakosta begitu terfokus pada pelayanan anak dan keluarga. 


\section{KESIMPULAN}

Alkitab menyatakan bahwa sukacita Tuhan adalah perlindungan dan kekuatan orang percaya (Neh. 8:10). Harus diakui bukanlah perkara mudah dan menjadi tantangan tersendiri bagi para orang tua Kristen untuk membawa sukacita Tuhan itu mengisi rumah tangga mereka. Lewat hasil penelitian artikel ini ada enam cara praktis bagaimana orang tua membangun ekosistem sukacita di keluarga orang percaya yaitu melalui orang tua yang tidak suka marah-marah, menghindari bertengkar dengan pasangan, membangun budaya senda gurau, hidup dalam standar moral yang Alkitab ajarkan, mengembangkan komunikasi bahasa cinta, dan jadi teladan. Ketika keenam hal ini diusahakan secara maksimal oleh para orang tua Kristen maka peneliti meyakini ekosistem sukacita akan terbentuk di setiap keluarga Kristen. Kiranya artikel ini bisa menjadi pemantik para orang tua untuk mengupayakan ekosistem sukacita di keluarga mereka dan bagi para akademisi maupun penggiat literasi kiranya artikel ini bisa dijadikan bahan rujukan untuk menulis artikel terkait topik keluarga, sukacita, maupun teologi Pentakosta. 


\section{DAFTAR PUSTAKA}

Arrington, F. L. (2020). DOKTRIN KRISTEN PERSPEKTIF PENTAKOSTA. Yogyakarta: ANDI Offset.

Budiyana, H. (2018). PERSPEKTIF ALKITAB TERHADAP KELUARGA KRISTEN. REGULA FIDEI: Jurnal Pendidikan Agama Kristen, 3(2), 581-589. https://doi.org/https://doi.org/10.33541/regula\%20fidei.v3i2.983

Chapman, G., \& Campbell, R. (2018). The 5 love Languages of Children. Yogyakarta: ANDI Offset.

Cristian Runturambi, M. (2018). MAKNA TEOLOGI PERAYAAN NATAL YESUS KRISTUS. Tитои Tou, VI(1), 41-58. Retrieved from http://ejournal-iaknmanado.ac.id/index.php/tumoutou/article/view/79/153

Eliasaputra, M. P., Novalina, M., \& Siahaan, R. J. (2020). TANTANGAN PENDIDIKAN AGAMA KRISTEN DI ERA REVOLUSI INDUSTRI 4.0 DAN PASCA KEBENARAN. BONAFIDE: Jurnal Teologi Dan Pendidikan Kristen, 1(1), 1-22. https://doi.org/10.46558/bonafide.v1i1.7

Friedman, A. N. (2016). Medical Ethics in Nephrology: A Jewish Perspective. Rambam Maimonides Medical Journal, 7(2), 14. https://doi.org/10.5041/rmmj.10241

Hadi, N. (2019). Pendidikan Teologi Lintas Agama dalam Meraih Keluarga Bahagia (Analisis Teori Islam, Kristen, Hindu, Budha dan Konghucu). AL-USWAH: Jurnal Riset Dan Kajian Pendidikan Agama Islam, 1(2), 67-87. https://doi.org/10.24014/au.v1i2.5224

Hendra, V. (2018). Peran Orang Tua Dalam Menerapkan Kasih dan Disiplin Kepada Anak Usia 2-6 Tahun Sebagai Upaya Pembentukkan Karakter. Kurios, 3(1), 48. https://doi.org/10.30995/kur.v3i1.29

Iskandar, I. (2016). Implementasi Teori Hirarki Kebutuhan Abraham Maslow terhadap Peningkatan Kinerja Pustakawan. Khizanah Al-Hikmah: Jurnal Ilmu Perpustakaan, Informasi, Dan Kearsipan, 4(1), 23-34. https://doi.org/10.24252/kah.v4i1a2

Jannah, M., Yakob, F., \& Julianto, J. (2017). RENTANG KEHIDUPAN MANUSIA (LIFE SPAN DEVELOPMENT) DALAM ISLAM. GENDER EQUALITY International Journal of Child and Gender Studies, 3(1), 97-114. https://doi.org/http://dx.doi.org/10.22373/equality.v3i1.1952

Juanda, J., \& Eveline, S. (2018). Membangun Komunikasi Suami-Istri Sebagai Sarana Keharmonisan Keluarga. Journal Kerusso, 3(1), 1-7. https://doi.org/10.33856/kerusso.v3i1.79

Katarina, K., \& Darmawan, I. P. A. (2019). Alkitab dalam Formasi Rohani pada Era Reformasi Gereja dan Implikasi bagi Gereja Pada Masa Kini. EPIGRAPHE: Jurnal Teologi Dan Pelayanan Kristiani, 3(2), 81. https://doi.org/10.33991/epigraphe.v3i2.85

Keriapy, F. (2020). Pendidikan Kristiani Transformatif Berbasis Multikultural dalam Konteks Indonesia. Regula Fidei: Jurnal Pendidikan Agama Kristen, 5(2), 82-93. 
Manalu, E. O. (2020). Pengaruh Konseling Pranikah Terhadap Keutuhan Keluarga. ANTUSIAS Jurnal Teologi Dan Pelayanan, 6(1), 16-31. Retrieved from https://www.sttintheos.ac.id/ejournal/index.php/antusias/article/view/303

Manurung, K. (2019). Studi Analisis Kontekstual Ajaran Karunia Nubuat Rasul Paulus sebagai Dasar Evaluasi Kritis terhadap Fenomena Bernubuat di Gereja Beraliran Karismatik. DUNAMIS: Jurnal Teologi Dan Pendidikan Kristiani, 4(1), 37-54. https://doi.org/10.30648/dun.v4i1.189

Manurung, K. (2020a). Efektivitas Misi Penginjilan dalam Meningkatkan Pertumbuhan Gereja. DUNAMIS: Jurnal Teologi Dan Pendidikan Kristiani, 4(2), 225-233. https://doi.org/10.30648/dun.v4i2.242

Manurung, K. (2020b). MEMAKNAI KEMARAHAN ALLAH DARI SUDUT PANDANG TEOLOGI PENTAKOSTA DI ERA POST MODERN. VISIO DEI: JURNAL TEOLOGI KRISTEN, 2(2), 307-328. https://doi.org/https://doi.org/10.35909/visiodei.v2i2.162

Manurung, K. (2020c). Taurat dan Nubuat Palsu: Kajian Sudut Pandang Taurat Terhadap Nubuat Palsu. Jurnal Teologi Berita Hidup, 2(2), 94-109. https://doi.org/10.38189/jtbh.v2i2.31

Novalina, M. (2020). Spiritualitas Orang Kristen Dalam Menghadirkan Kerajaan Allah di Tengah Tantangan Radikalisme. Jurnal Teologi Kontekstual Indonesia, 1(1), 26. https://doi.org/10.46445/jtki.v1i1.293

Prabowo, W. (2020). Aplikasi Prinsip Mazmur 2:11-12 dalam Peribadahan Kristen. Jurnal Teologi Berita Hidup, 2(2), 128-141. https://doi.org/10.38189/jtbh.v2i2.34

Pranoto, M. M. (2017). KESEMBUHAN, PENEBUSAN, DAN KEBAIKAN ALLAH DALAM TEOLOGI PENTAKOSTAL. Jurnal Abdiel: Khazanah Pemikiran Teologi, Pendidikan Agama Kristen, Dan Musik Gereja, 1(01), 81-98. https://doi.org/10.37368/ja.v1i01.88

Rossandy, A. N. B. (2016). HAKIKAT HIDUP MANUSIA DENGAN SESAMANYA DALAM TEMBANG MACAPAT. EDu-KATA Jurnal Bahasa, Sastra, Dan Pembelajarannya, 3(2), 189-196. Retrieved from http://e-jurnal.unisda.ac.id/index.php/kata/article/view/1049

Roy, B., \& Yosef, A. (2019). PERTUMBUHAN ROHANI ANAK DALAM KELUARGA KRISTEN MENURUT EFESUS 6:4. Jurnal The Way, 5(1), 52-69. Retrieved from https://journal.sttbetheltheway.ac.id/index.php/teologi-dan-kependidikan/article/view/4/4

Saragih, A., \& Hasugian, J. W. (2020). Model Asuhan Keluarga Kristen di Masa Pandemi Covid19. JURNAL TERUNA BHAKTI, 3(1), 1. https://doi.org/10.47131/jtb.v3i1.56

Siahaan, H. E. (2015). MEMAHAMI PENTAKOSTALISME MELALUI BINGKAI HISTORIOGRAFI LUKAS DALAM KISAH PARA RASUL. ANTUSIAS Jurnal Teologi Dan Pelayanan, 4(7), 105-126. Retrieved from https://www.sttintheos.ac.id/ejournal/index.php/antusias/article/view/6

Siahaan, H. E. R. (2017). Karakteristik Pentakostalisme Menurut Kisah Para Rasul. DUNAMIS: Jurnal Penelitian Teologi Dan Pendidikan Kristiani, $2(1), \quad 12$. https://doi.org/10.30648/dun.v2i1.132

Sitompul, R. M. (2017). Makna Perkataan Paulus Tentang Hidup Adalah Kristus Dan Mati Adalah Keuntungan Berdasarkan Filipi 1:12-26. Jurnal Jaffray, 15(2), 153. 
https://doi.org/10.25278/jj71.v15i2.242

Soesilo, Y. (2018). Pentakostalisme dan Aksi Sosial: Analisis Struktural Kisah Para Rasul 2:41-47. DUNAMIS: Jurnal Teologi Dan Pendidikan Kristiani, 2(2), 136-151. https://doi.org/10.30648/dun.v2i2.172

Stevanus, K. (2018a). Mengimplementasikan Pelayanan Yesus Dalam Konteks Misi Masa Kini Menurut Injil Sinoptik. FIDEI: Jurnal Teologi Sistematika Dan Praktika, 1(2), 284-298. https://doi.org/10.34081/fidei.v1i2.21

Stevanus, K. (2018b). Tujuh Kebajikan Utama Untuk Membangun Karakter Kristiani Anak. BIA': Jurnal Teologi Dan Pendidikan Kristen Kontekstual, 1(1), 79-95. https://doi.org/10.34307/b.v1i1.21

Sudaryanti, S. (2017). MENDIDIK ANAK MENJADI MANUSIA YANG BERKARAKTER. Jurnal Pendidikan Anak, 3(2), 506-517. https://doi.org/10.21831/jpa.v3i2.11706

Sukono, D. (2019). Alkitab: Penyataan Allah Yang Diilhamkan. PASCA : Jurnal Teologi Dan Pendidikan Agama Kristen, 15(1), 28-34. https://doi.org/10.46494/psc.v15i1.66

Sunariyanti, S. (2020). Penerapan Etika Kristen dalam Pendidikan Anti Korupsi di Keluarga. SANCTUM DOMINE: JURNAL TEOLOGI, 7(1), 107-120. https://doi.org/10.46495/sdjt.v7i1.46

Supatra, H. (2019). MENGENAL PENTAKOSTALISME DI INDONESIA. Jurnal Abdiel: Khazanah Pemikiran Teologi, Pendidikan Agama Kristen, Dan Musik Gereja, 3(2), 11-24. https://doi.org/10.37368/ja.v3i2.97

Surya Gani, D., \& Budi Lestari, S. (2018). Komunikasi dan Pola Asuh Anak dalam Membangun Keharmonisan pada Keluarga Tenaga Kerja Indonesia (Kasus pada Tenaga Kerja Indonesia di Sojomerto, Kendal). Interaksi Online, 6(4), 306-310. Retrieved from https://ejournal3.undip.ac.id/index.php/interaksi-online/article/view/21692

Suteja, J. (2017). DAMPAK POLA ASUH ORANG TUA TERHADAP PERKEMBANGAN SOSIAL-EMOSIONAL ANAK. AWLADY: Jurnal Pendidikan Anak, 3(1). https://doi.org/10.24235/awlady.v3i1.1331

Sutoyo, D. (2018). Analisis Historis terhadap Teologi Gerakan Pentakostalisme. DUNAMIS: Jurnal Teologi Dan Pendidikan Kristiani, 2(2), 167. https://doi.org/10.30648/dun.v2i2.171

Tandy K, P. (2016). KARAKTER PENDIDIK KRISTEN DAN NILAI-NILAI KERAJAAN ALLAH ANALISIS INJIL MATIUS. REGULA FIDEI: Jurnal Pendidikan Agama Kristen, 1(1), 163-188. https://doi.org/https://doi.org/10.33541/regula\%20fidei.v1i1.147

Tari, E., \& Tafonao, T. (2019). Tinjauan Teologis-Sosiologis terhadap Pergaulan Bebas Remaja. DUNAMIS: Jurnal Teologi Dan Pendidikan Kristiani, $3(2), \quad 199$. https://doi.org/10.30648/dun.v3i2.181

Tua, E. M. (2017). Respon Daud Dalam Menghadapi Pergumulan: Studi Terhadap Kitab Mazmur 3:1-9. Evangelikal: Jurnal Teologi Injili Dan Pembinaan Warga Jemaat, 1(1), 75. https://doi.org/10.46445/ejti.v1i1.59

Xiao, A. (2018). KONSEP INTERAKSI SOSIAL DALAM KOMUNIKASI, TEKNOLOGI, 
MASYARAKAT. Jurnal Komunika: Jurnal Komunikasi, Media Dan Informatika, 7(2), 9499. https://doi.org/10.31504/komunika.v7i2.1486

Zaluchu, S. E. (2019). Eksegesis Kisah Para Rasul 2:42-47 untuk Merumuskan Ciri Kehidupan Rohani Jemaat Mula-mula di Yerusalem. EPIGRAPHE: Jurnal Teologi Dan Pelayanan Kristiani, 2(2), 72. https://doi.org/10.33991/epigraphe.v2i2.37

Zaluchu, S. E. (2020). Strategi Penelitian Kualitatif dan Kuantitatif Di Dalam Penelitian Agama. Evangelikal: Jurnal Teologi Injili Dan Pembinaan Warga Jemaat, 4(1), 28. https://doi.org/10.46445/ejti.v4i1.167 